\title{
Coğrafi İşaretli Türkiye Peynirleri ${ }^{1}$
}

\author{
Derya SAYGILI \\ İmir Kavram Meslek Yüksek Okulu, Aşçılık Programı, İzmir \\ derya.saygili@kavram.edu.tr; https://orcid.org/0000-0002-5286-4359 \\ Hande DEMIRCI \\ İzmir Kavram Meslek Yüksek Okulu, Aşçılık Programı, İzmir \\ hande.kurt@kavram.edu.tr; https://orcid.org/0000-0001-8072-3345 \\ Ufuk SAMAV \\ İzmir Kavram Meslek Yüksek Okulu, Aşçılık Programı, İzmir \\ ufuk.samav@gmail.com; https://orcid.org/0000-0003-1966-4977
}

Geliş tarihi/Received: 05.09.2019

Kabul tarihi / Accepted: 24.11.2019

\section{Öz}

Türkiye, coğrafi konumu itibariyle tarımsal ve hayvansal ürün çeşitliliğinin fazla olduğu ve bunun yanı sıra farklı kültürlerden gelen toplumların bir arada bulunmasıyla zengin mutfak kültürünün oluştuğu bir ülkedir. Sahip olduğumuz bu zengin yöresel mirasın korunabilmesi için tescil işleri günümüzde Türk Patent ve Marka Kurumu tarafindan yürütülmekte ve ürünlerde coğrafi işaretleme uygulaması yapılmaktadır. Bugüne kadar 32 farklı peynir çeşidi için yapılan başvurudan Antep sıkma peyniri, Diyarbakır örgü peyniri, Edirne beyaz peyniri, Erzurum çivil peyniri, Erzurum küflü çivil peyniri, Erzincan tulum peyniri, Ezine peyniri, Karaman Divle obruğu peyniri, Kars kaşarı, Yozgat çanak peyniri, Antakya sürkü, Antakya küflü sürkü, Malkara eski kaşar peyniri ve Van otlu peyniri coğrafi işaret almaya hak kazanmıştır. Bu çalışmada zengin kültürel mirasımız ile özdeşleşmiş ürünlerimize sahip çıkmak ve bu mirası gelecek nesillere devrederken coğrafi işaretli peynirlerin tanıtılması hedeflenmiştir.

Anahtar Kelimeler: Coğrafi işaret, gastronomi, peynir, turizm

\footnotetext{
${ }^{1}$ Bu makale 25-26 Nisan 2019 Ulusal Sütçülük Kongresinde Poster bildiri olarak sunulmuştur.
} 


\title{
Geographically Marked Turkish Cheeses
}

\begin{abstract}
Turkey is a country with a wide varietyof agricultural and animal products due to its geographical location as well as has a rich culinary culture due to the combination of communities from different cultures. In order to preserve this rich local heritage, registration works are carried out by the Turkish Patent and Trademark Authority and geographical marking is applied to the products. Today, Antep s1kma cheese, Diyarbakır knit cheese, Edirne white cheese, Erzurum civil cheese, Erzurum moldy civil cheese, Erzincan tulum cheese, Ezine cheese, Karaman Divle obruk cheese, Kars kaşar cheese, Yozgat çanak cheese, Antakya sürk cheese, Antakya moldy sürk cheese, Malkara old kaşar cheese and Van otlu cheese were entitled to geographical indication. In this study, it is aimed to protect our products identified with our rich cultural heritage and to introduce geographically marked cheeses while transferring this heritage to future generations.
\end{abstract}

Keywords: Geographical indication, gastronomy, cheese, tourism

\section{GİRIȘ}

İnsanoğlu dünyaya gelişi ile birlikte temel gıdamız olan süt ile tanışır. Süt, anne ile bebeğin ilk tanışma aracı iken aynı zamanda yüksek besleyici özelliği onu vazgeçilmez kılmaktadır. Bebeklikten yetişkinliğe doğru günlük beslenmenin bir parçası olan süt ve süt ürünleri içerisinde, daha uzun süre muhafaza edilebiliyor olması peynir çeşitlerini ön plana çıkarmaktadır. Peynir, insanoğlunun uygarlığa geçişinin ilk simgelerinden biri iken aynı zamanda kültür zenginliğinin de bir işareti olarak tüketilen geleneksel bir üründür. Geleneksel gıdalar ise medeniyetlerin mirasını taşıyan ürünler olarak orijinal karakteristiklerine zarar vermeden nesilden nesile aktarılması gereken ürünlerdir. $\mathrm{Bu}$ çerçevede karşımıza coğrafi işaretleme kavramı çıkmaktadır. Coğrafi işaretleme, küreselleşme sürecinde çeşitli bölgelere has gıdalara kolaylıkla ulaşan tüketicilerin, yediği g1danın orijinini bilme ihtiyacina binaen ortaya çıkmış bir kavramdır (Ekinci, 2014). Sağlıklı, kaliteli ve güvenilir gıda arayışı içerisinde olan tüketiciler için coğrafi işaret kavramı ürünün katma değerini arttırmaktadır. Kendine has özellikleri ile coğrafi işaret almaya hak kazanan ürünler aynı zamanda bölge halkı ve yöreye de büyük katkı sağlamaktadır. Bölgede oluşan istihdam, ekonomik hareketlenme ve diğer ürünler ile ortaya çıkan rekabet ortamı da coğrafi işaretlemenin sağladığ 1 katkılar arasında sayılabilmektedir.

\section{Coğrafi İşaret}

Ülkemizin üç farklı iklime sahip oluşu, coğrafi konumu, farklı toprak yapısı ve kültürel miras çeşitliliği, bu topraklara özgü ürün ve imalat tekniklerini ortaya çıkarmıştır. Bu farklılık ülkemizin coğrafi işarete konu olabilecek ürün çeşitliliğine sahip olduğunu göstermektedir (Gökovalı, 2007).

Toplumun sosyoekonomik değişmelerle birlikte tüketim yapısında farklılıklar meydana gelmekte, alışkanlıklar ve zevkler değişime uğramaktadır. Gıda, tarım ve temel ihtiyaçların üretiminde çoğunlukla kullanılan yeni teknolojilerin yanında yerel ve geleneksel ürünlere karşı ilgi hızla artmaktadır (Şahin ve Meral, 2012). Coğrafi işaretler (menşe adı ve mahreç işareti); belirgin özellikleri, ünü, kökeninin bulunduğu bölge veya ülke ile bütünleşmiş ürünü gösteren, ürünün kaynağını ifade eden işaretlerdir. Söz konusu işaretler yerel tarım faaliyetlerini destekleyerek 
coğrafi işaretli ürünlerin yetiştirildiği bölgenin tanıtımını yapmaktadır. Ayrıca yerel değerler ile geleneksel miras koruma altına alınmaktadır (Şentürk, 2011). Niteliği, ünü veya özellikleriyle kökeninin bulunduğu yer ile özdeşleşen ürünü gösteren işaret olarak tanımlanan coğrafi işaretin tescili iki şekilde yapilabilmektedir:

- Menşe adı; ürünün üretimi, işlenmesi ve diğer işlemlerinin tamamı sınırları belirlenmiş coğrafi alanda gerçekleşmek zorunda olan ürünlere verilen ad iken,

- Mahreç işareti; ürünün üretimi, işlenmesi ve diğer işlemlerden en az biri sınırları belirlenmiş coğrafi alanda gerçekleşmek zorunda olan ürünlere verilen ad olarak tanımlanmaktadır (Türkiye Patent Enstitüsü [TPE], 2019).

Menşe adı tescilinde ürünler, ancak ait oldukları bölge içerisinde üretilir ise özelliklerini kazanabilmektedir. Mahreç işaretli ürünler ise niteliklerinden en az birinin ait olduğu yöreden kaynaklanması kaydıyla başka bir bölgede üretilebilmektedir. Ancak üretim yöntemleri ve ürün kalitesi aynı olmak zorundadır (Türkiye Esnaf ve Sanatkârları Konfederasyonu [TESK], 2019).

Coğrafi işaret tescilinde bölgeye özgü özelliklerin ürüne kazandırdığı kalite ve benzer ürünlerden ayırt edilmesini sağlayan öznellik en temel amaçlardandır. Bu tescil yöntemiyle söz konusu ürünlerin korunması mümkün olmaktadır (Ayber, 2005). Coğrafi işaret ile ürünlerin korunması; pazarlama imkânlarının arttırılması, üreticinin korunması ve ekonomik kazanç ile kırsal kalkınmaya katkıda bulunması gibi avantajlar sağlamaktadır. Coğrafi işaretlerin incelenmesi ülke ekonomisi açısından, söz konusu avantajlardan hangi ölçüde faydalanıldığının ortaya konması bakımından önemlidir (Gökoval1, 2007).
Kaliteyi önemseyen tüketiciler tarafindan yöresel ürünler, coğrafi işaret amblemleri ile tanınmaktadır. Yöresel ürünler ile bu ürünlerin üretildikleri bölgeler arasında güçlü bağlar bulunmaktadır. Ürünlerin taklit edilmesini önlemek, mahsulü haksız rekabetten korumak, ürün isimlerinin yanlış kullanılmasını önlemek, tarımürün çeşitliliğini teşvik etmek ve ürünlerin özellikleri hakkında tüketiciyi bilgilendirmek adına yasal düzenlemeler yapılmıştır. Uluslararası alanda bu kavram menşe adı ve coğrafi işaretler koruması kapsamında yapılan düzenlemelerle sözleşmelerde yer almaktadır (Tekelioğlu ve Demirer, 2008; Gürsu-Doğu, 2008). Ülkemizde ise Tescil işlemleri 1995 yılında çıkarılan 555 sayılı KHK ile Türk Patent Enstitüsü tarafindan yürütülmektedir. Türkiye'nin tescilli coğrafi işaretlerinin, yerel el sanatları, gastronomi, gelenek ve görenekler, yerel yaşam tarzları ve yerel sembollerin turizm ürünü olarak harekete geçirilmesi hem yerli hem yabancı turistleri Türkiye'nin farklı özelliklere sahip bölgelerine çekmektedir. Bu durum da coğrafi işaretli ürünlerin bölgesel kalkınma aracı olarak kullanılmasına olanak sağlamaktadır.

\section{Türkiye ve Peynir}

Süt ürünleri içerisinde geniş ürün yelpazesi ile karşımıza çıkan peynirler tüm dünyada olduğu gibi ülkemiz genelinde de sevilerek tüketilmektedir. Yazılı olarak Kâşgarlı Mahmud'un Dîvânü Lugati't-Türk kitabında uyutmak, uyumuş süt ve peynir anlamlarında "udma veya udhıtma" olarak geçen peynir terimi için kurut, çökelek, bışlak, ağrımışık, kesük gibi ifadeler de kullanılmıştır (Karaca, 2016). Geçmişten bugüne temel gıdalarımızdan biri olan peynirler süt ürünleri içerisinde dayanıklılı̆g 1 daha uzun ve kalsiyum miktarı bakımından zengin gidalar olması sebebi ile önem arz etmektedir. Kişi başına düşen yıllık peynir tüketimimiz gelişmiş ülkeler arasında son sıralarda yer almasına rağmen, ülkemiz süt 
sanayinde üretilen toplam çiğ sütün en önemli payını peynir üretimi kapsamaktadır.

Anadolu, coğrafi konumu sebebi ile farklı kültürlerin bir araya geldiği ve geleneksel lezzetlerin harmanlandığ 1 bir merkez niteliğindedir. Yöresel olarak üretilip tüketilen peynirlerin yanı sıra ülkemizde en çok tercih edilen peynir çeşitleri beyaz, kaşar ve tulum peynirleri olarak sıralanmaktadır. Ülkemizde peynir çeşitliliğinin ortaya çıkmasında pek çok faktör etkili olmuştur. Sütün elde edildiği hayvanın cinsi, uygulanan 1 sıl işlem, üretim yöntemi, sütün bileşimi, üretimde kullanılacak olan katkı maddesi dahi elde edilecek olan peynirin çeşidinde etkin rol oynamaktadır. Bunun yanı sira elde edilen peynirin üretim sonrasinda hemen tüketilmesi veya olgunlaştırılması gibi işlemler ve üretildiği yörenin kendine özgü kültürel mirası peynir yapisının oluşmasında önemli parametreler arasında yer almaktadır. Kars kaşarı, Edirne beyaz peyniri, Erzincan tulumu, Ezine peyniri, Erzurum civil peyniri ve Diyarbakır örgü peyniri coğrafi işaretli peynirlerimiz arasında daha çok tanınmış ve bölgesel üretimi aşmayı başarmış peynirlerimizdendir. Ülkemizde üretimiyapılan ancakbölgesel tüketiminötesine geçememiş olan peynirler arasında coğrafi işaret almış peynirlerimiz de bulunmaktadır. Karaman Divle obruğu tulum peyniri, Antep sıkma peyniri, Antakya sürkü, Erzurum küflü civil peyniri, Yozgat çanak peyniri ve Antakya küflü sürkü üretildiği yöre halkı tarafindan severek tüketilen peynirler olmasına rağmen bölge dışında pek fazla tanınmaması sebebi ile üretim rakamları düșük seviyelerde kalmıștır. Zengin kültürel mirasa sahip ülkemizin pek çok köşesinde farklı özelliklere sahip peynir çeşitleri bulunmaktadır. Tüketim rakamları üretildiği bölge ile kısıtlı kalan peynirler ülkemiz genelinde ticari potansiyeli bulunan ancak ulusal boyuta taşınamayan ürünler statüsündedir. Üretildiği şehir veya bölge adı ile anılan, kendine has lezzet karakteristikleri taşıyan peynirlerimizin daha fazla tanınması ve tüketiminin yaygınlaşması amacıyla süt endüstrisine büyük görev düşmektedir. Fabrikasyon boyutunda bir üretim söz konusu olduğunda yöresel peynirlerimize has tat, lezzet, aroma profilinin korunması önem arz ederken kalite artışının ürünün orijinal yapısında değişikliklere sebebiyet vermemesi gerekmektedir.

\section{Coğrafi İşaretli Türkiye Peynirleri}

Süt ve süt ürünleri içerisinde en çok tüketilen ürün çeşidi olan peynirler üretim metotları ve uygulanan teknoloji ile farkl fizikokimyasal özellikler kazanmaktadır. Isıl işlem, tuzlama, kurutma, olgunlaştırma gibi pek çok teknolojik işlem ile peynirlere istenen lezzet ve aroma profili kazandırılmaktadır. Ülkemiz genelinde coğrafi işaret almış peynirler şu şekilde sıralanmaktadir:

\section{Antep Peyniri / Gaziantep Peyniri / Antep Stkma Peyniri}

Antep s1kma peyniri, 2018 tarihinde coğrafi işaret alan Gaziantep ilinde üretilen yöresel peynirlerimizdendir. Gaziantep'te "pişken" ya da "kelle" olarak da adlandırılan peynir meralarda otlatılan küçükbaş hayvanların sütlerinden üretilmektedir. Antep peyniri, homojen, gözeneksiz, pürüzsüz, sık1, kesilince ufalanmayan, yarı sert, esnek ve ağızda kolayca dağılan bir yapıya sahiptir. Çiğnenmesi esnasında ağızda gıcırdama hissi bırakan peynir rengi grimsi beyazdır. Düzgün olmayan oval (el ayası benzeri) bir şekle sahip olmasının sebebi ise geleneksel olarak avuç içerisinde şekillendirilmesidir (TPE, 2019). Antep peyniri,homojen, gözeneksiz, pürüzsüz, sık1,kesilince ufalanmayan, yarı sert, esnek ve ağızda kolayca dağılan bir yapıya sahiptir (Şekil 1). 


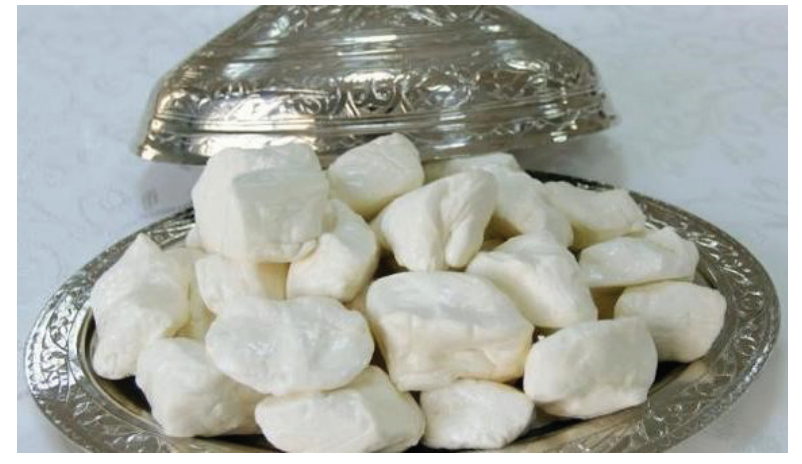

Şekil 1: Geleneksel Antep sıkma peyniri

\section{Diyarbakır Örgü Peyniri}

Genellikle ilkbahar aylarında koyun sütünden yapıldığ1 bilinen peynir, keçi ve inek sütü karışımından da üretilebilmektedir. Üretim teknolojisi yönünden kaşar peynirine benzeyen peynirin, kendine has aromas1, rengi krem beyaz, parlak görünümde yapısı istenildiğinde elle iplik şeklinde ayrılabilir özelliktedir. Tipik saç örgüsü şekli ile tüketici beğenisini kazanan Diyarbakır örgü peyniri, ülkemiz genelinde tanınan ve sevilerek tüketilen peynirler arasındadir (TPE, 2019). Beyaz, parlak görünümde yapısı istenildiğinde elle iplik şeklinde ayrılabilir özelliktedir (Şekil 2).

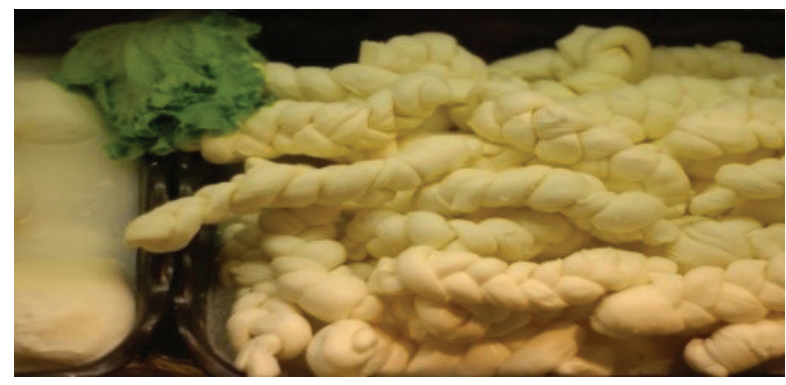

Şekil 2: Diyarbakır örgü peyniri

\section{Edirne Beyaz Peyniri}

Edirne beyaz peyniri genellikle salamurada veya tenekede üretilmektedir. Türkiye'nin her yerinde üretilip tüketilmesine rağmen özellikle Trakya, Marmara, Ege bölgelerinde yoğun olarak tercih edilmektedir. Kendine has kokusu, tadı ve yapısı olan peyniri değişik kılan özellikleri ise Edirne'nin coğrafi konumu ve üretildiği sütün çeşidine göre değişiklik göstermesidir. Salamurada tuzlanarak olgunlaştırılan beyaz peynir üretiminde en önemli noktalardan biri ise peynirlerin gözeneksiz ve düz bir yapıya sahip olmasıdır (Durlu-Özkaya ve Gün, 2007). 2007 yılında mahreç işareti alan Edirne beyaz peyniri, ülkemizde en yaygın tüketilen coğrafi işaretli peynir çeşididir. (Şekil 3).

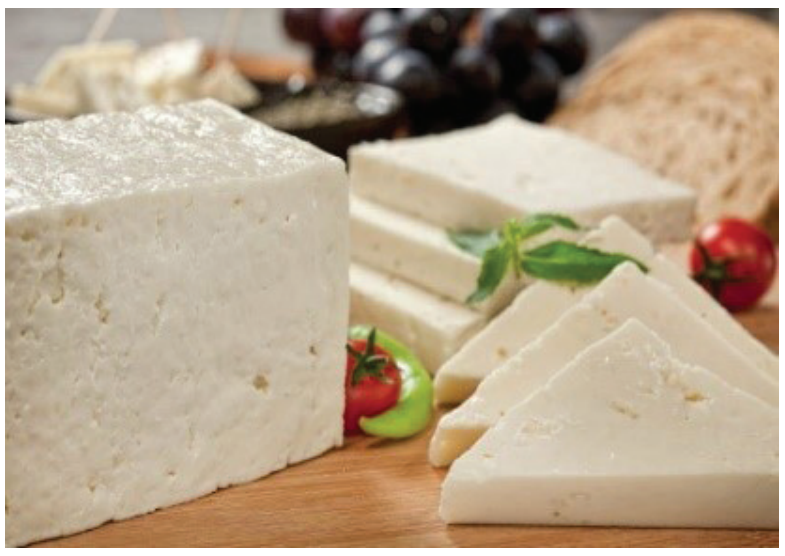

Şekil 3: Edirne beyaz peyniri

\section{Erzurum Civil Peyniri}

Erzurum civil peyniri, 2009 tarihinde coğrafi işaret alan başta Erzurum olmak üzere Kars, Ağrı gibi birçok ilimizde de üretilen yöresel peynirlerimizdendir (Hayaloğlu ve Özer, 2011). İçeriğinde yüksek oranda protein, kalsiyum ve fosfor bulundurmasına rağmen düşük yağ oranına sahiptir (Baran ve Topçu, 2018). Isıl işlem uygulanarak pihtılaştırılan peynirin olgunlaştırmasında askılara asılarak tel (lif) haline getirilmesi (Şekil 4) amaçlanmaktadır. Coğrafi işaret almış Erzurum civil peyniri, yerel halk tarafından en çok tüketilen küflü civil peynirinden (Şekil 5) sonra ikinci sırada tercih edilen peynir çeşididir. 


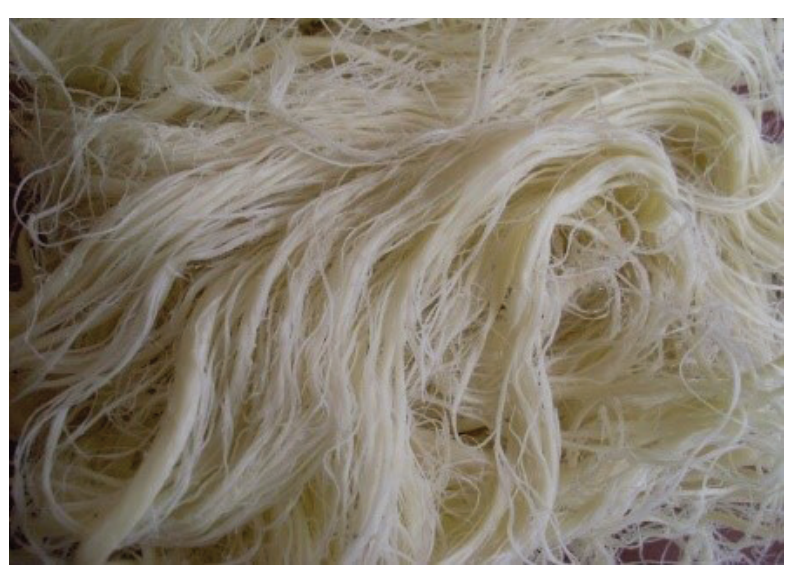

Şekil 4: Erzurum civil peyniri

\section{Erzurum Küflü Civil (Göğermiş) Peyniri}

Erzurum'un yerel halkı tarafından daha fazla tüketilen Erzurum küflü civil peyniri, civil peyniri ile aynı özellikler ve yapım sürecine sahiptir. Yöresel olarak "göğermiş peynir" olarak da bilinen peynir olgunlaştırma esnasinda plastik, ahşap veya deri gibi materyallere basılarak peynirin mavi ve yeşil renkli küflendirilmesi yapılmaktadır (Topçu, 2018). Mahreç işareti alan peynir Erzurum civil peynirinden 3 yıl sonra coğrafi işaret almaya hak kazanmıştır.

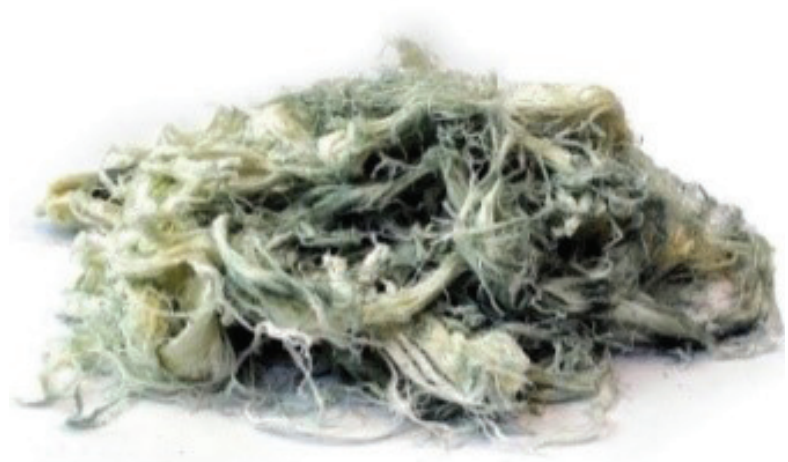

Şekil 5: Erzurum küflü civil peyniri

\section{Erzincan Tulum Peyniri}

Peynirin dayanıklılığını artırmak için uygulanan yöntemlerinden biri de tuluma basmaktır. Geleneksel yöntemler ile koyun sütünden elde edilen Erzincan tulum peyniri, 3 aydan 1 yıla kadar keçi derisinden hazırlanan tulumlara konularak, mağaralarda veya soğuk hava depolarında olgunlaştırılmaktadır (Hayaloğlu ve Özer, 2011). Tulum peynirleri içerisinde yaygın olarak tüketilen Erzincan tulum peyniri, besin değeri yüksek, gözeneksiz ve hafif keskin kokulu özelliği ile tanınmaktadır (Durlu-Özkaya ve Gün, 2007). Yarı sert özelliği olan bu peynir genellikle Erzincan ve Tunceli civarlarında üretilmektedir. Peynirin kendine has renginin tulum içerisinde olgunlaşması ile ilişkili olduğu bildirilmiştir. 2000 yılında coğrafi işaret almaya hak kazanan Erzincan tulum peyniri, aynı zamanda ilk olarak coğrafi işaret almış ürün olarak tanınmaktadır. (Şekil 6).

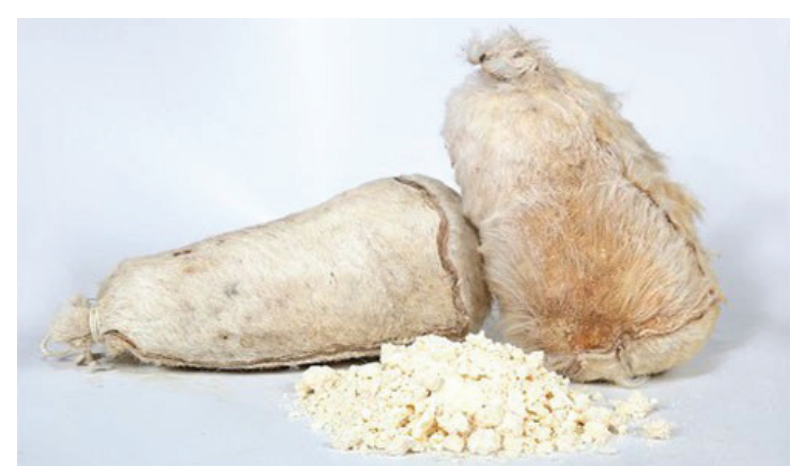

Şekil 6: Erzincan tulum peyniri

\section{Ezine Peyniri}

Ülkemizde üretilen beyaz peynirler içerisinde tam yağlı inek, koyun ve keçi sütü karışımlarından üretilen bir peynir çeşidi olan Ezine peynirinin en belirgin özelliği bölgede yetişen yağlı ve aromalı otlar ile beslenen hayvan sütüdür. 


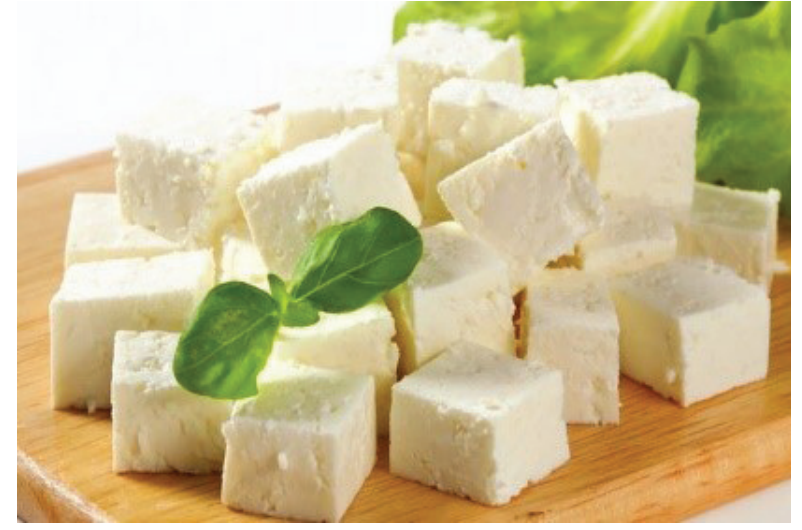

Şekil 7: Ezine peyniri

Ezine peyniri sıklıkla Çanakkale'nin Ezine, Bayramiç, Ayvacık ilçelerinde üretilmektedir. 2007 y1lında coğrafi işaret almaya hak kazanan Ezine peyniri, beyaza dönük açık sarı renkte olup yumuşak veya orta sertlikte ve kırılgan olmayan bir yapıya sahiptir (Şekil 7) (DurluÖzkaya ve Gün, 2007).

\section{Karaman Divle Obruğu Tulum Peyniri}

Karaman ilinin Ayrancı ilçesinde üretilen Divle Obruğu tulum peyniri geleneksel üretim şekli ile günümüze kadar ulaşmış yöresel peynirlerimizdendir (Şekil 8). Ürünün ismi olgunlaştırmasında yararlanılan Divle Obruğu'ndan gelmektedir. Peynir, keçi ve kuzu derisinden hazırlanmış tulumlarda 5-6 ay arası Divle Obruğu'nda olgunlaştırılmaktadır. $\mathrm{Bu}$ ürünü diğer tulum peynirlerinden ayıran özelliği ise kendine has yerleşik bir küf florasının olmasıdır. Obruk olarak isimlendirilen mağaraya konulan tulum peynirlerinin üzerlerinde yaklaşık 1 ay sonra mavi sonra beyaz ve daha sonra da kiremit kırmızısı renkli küf mantarları gelişmektedir. Tulumun dış yüzeyinin kiremit kırmızısı rengi alması peynirin tam olgunlaştığını göstermektedir (İşleyici ve Sancak, 2011; TPE, 2019).

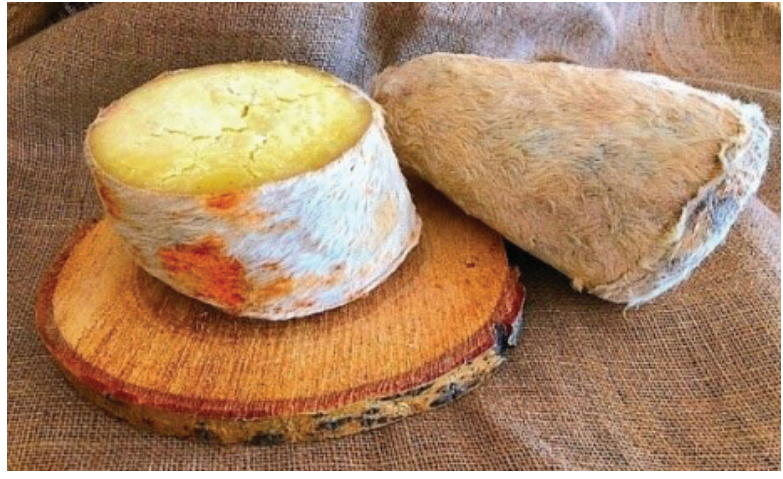

Şekil 8: Karaman Divle obruğu tulum peyniri

\section{Kars Kaşarı}

Kars ve Ardahan'ın merkez ve ilçelerinde üretimi yapılan Kars kaşarı telemesi haşlanarak üretilen peynirler grubunda yer almaktadır (Şekil 9).

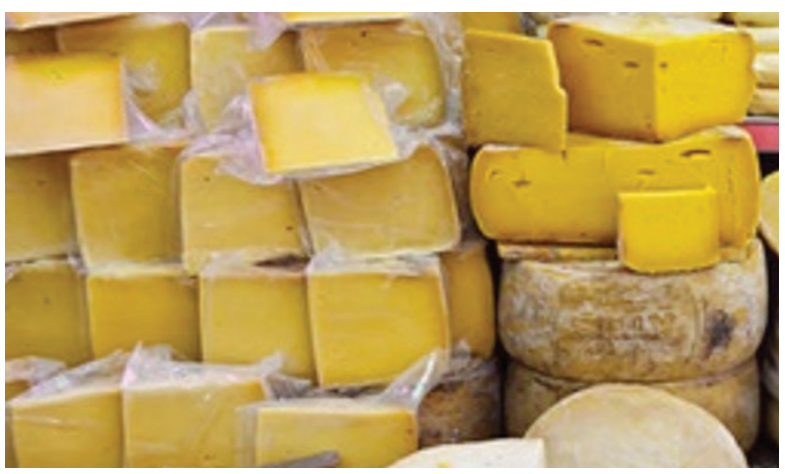

Şekil 9: Kars kaşar peyniri

1600 civarında çiçekli bitkinin bulunduğu ve bunlardan 80 civarında taksonun endemik, 20 civarında taksonun ise nadir olduğu meralarda otlayan hayvanların sütünden elde edilen peynirin kesit yüzeyi beyazımsı, hafif tuzlu ve ağızda kolayca dağılan bir yapıya sahiptir (Demir ve Derbentli, 2012; TPE, 2019).

\section{Yozgat Çanak Peyniri}

Yozgat çanak peyniri, 2017 tarihinde coğrafi işaret alan Yozgat merkez ve ilçelerinde üretilen yöresel peynirlerimizdendir. Yozgat'in doğal bitki örtüsü ve su kaynaklarıyla 
beslenen küçükbaş hayvanların sütlerinden üretilmektedir. Az olgun ve yarım yağll bir ürün olan peynir topraktan yapılmış çanak içine basıldıktan sonra kuma gömülerek olgunlaştırılır (Şekil 10). Olgunlaşma sırasında gömüldüğü kumun ince ve az çakıllı serin ve hafif rutubetli olması önem arz etmektedir (Akyüz ve Gülümser, 1984; TPE, 2019).

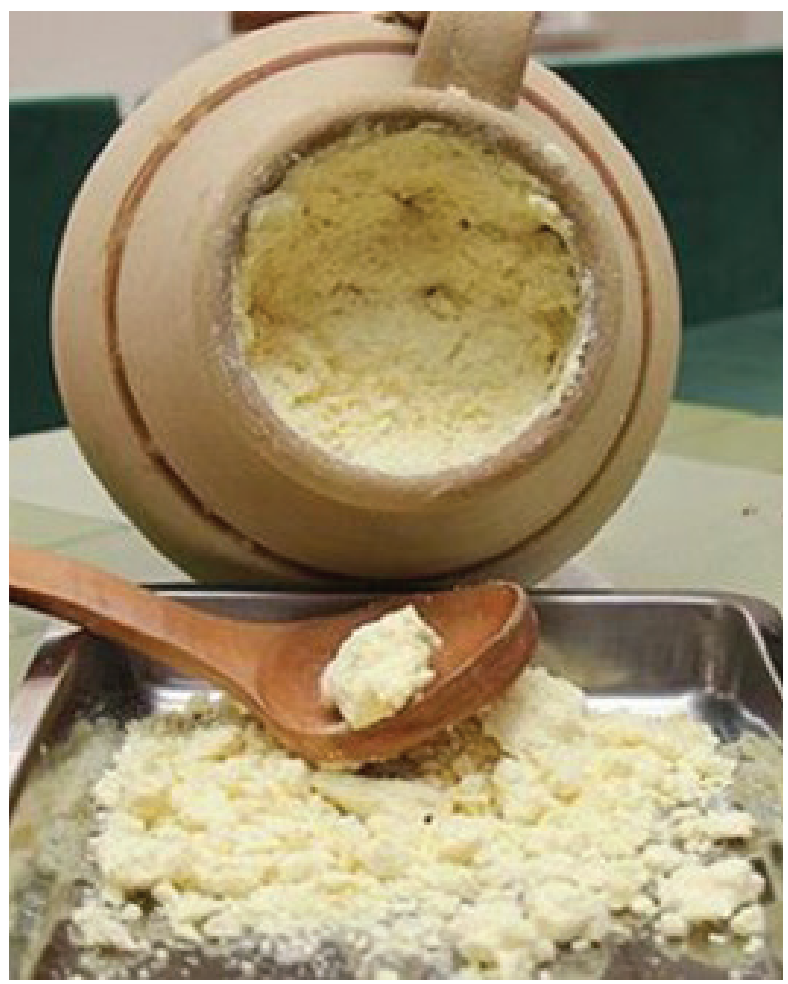

Şekil 10: Yozgat çanak peyniri

\section{Antakya Sürkü (Çökeleği)}

En önemli özelliği bölgede yaygın olarak dağlardan toplanan zahter bitkisinin kazandırdığı aroma olan Antakya sürkü'nün bileşiminde kırmızı acı biber, nane, kimyon, kişniş, mahlep, yenibahar, cincir, küçük hindistan cevizi, karanfil, karabiber, tarçın gibi pek çok baharat bulunmaktadır. Zahter veya karabaş kekiği olarak da bilinen bitkinin karvakrol içeriği yüksek bir kekik çeşidi olduğu ve özellikle Güney bölgelerinde yetiştiği bilinmektedir. Antakya sürkü asitliği ilerlemiş olan inek sütü veya yayıkaltı ayranının kaynatılmasının ardından zahter, tuz, biber salçası ve isteğe bağl1 diğer baharatların ilave edilip yoğurulması ile elde edilmektedir (Şekil 11). Konik şekli ve turuncu rengi ile karakteristik özelliğini kazanan Antakya sürkü, tuzlu, ekşi ve acı tatları bir arada barındıran bir tür çökelek çeşididir (Türkiye'nin Coğrafi İşaretleri, 2018a: TPE, 2019).

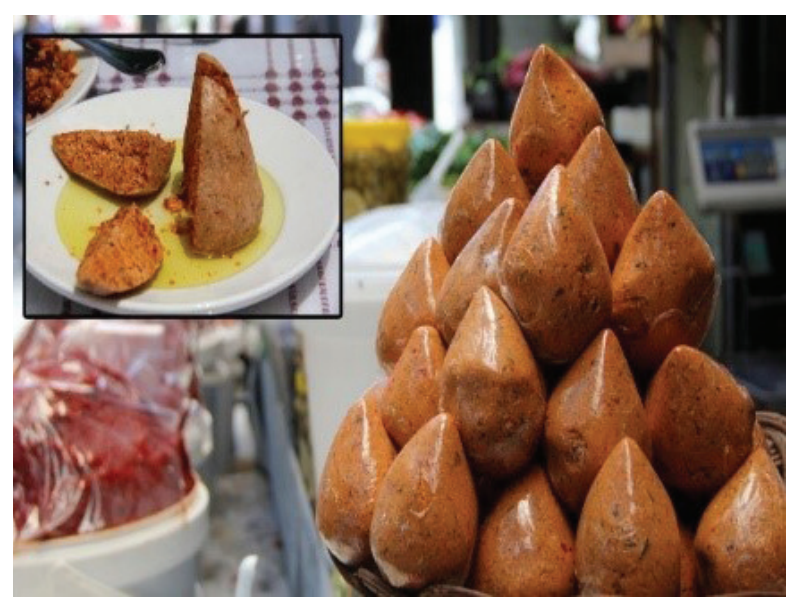

Şekil 11: Antakya Sürkü

\section{Antakya Küflü Sürkü (Çökeleği)}

Antakya sürkünün tescil almasının ardından yöre halkı tarafından severek tüketilen ve pişmiş olarak da adlandırılan Antakya küflü sürkü de mahreç işareti almıştır. Ülkemiz genelinde tüketilen diğer küflü peynirlerden farklı olarak küfle olgunlaşması sağlanan peynir, üzerindeki küf tabakası uzaklaştırılarak tüketilmektedir (Şekil 12). Dışında sert bir kabuk oluşumu gözlenirken, rengi koyu kırmızıdan kahverengiye değişen bu çökelek çeşidi için endüstriyel üretim henüz söz konusu değildir (Türkiye'nin Coğrafi İşaretleri, 2018b). 


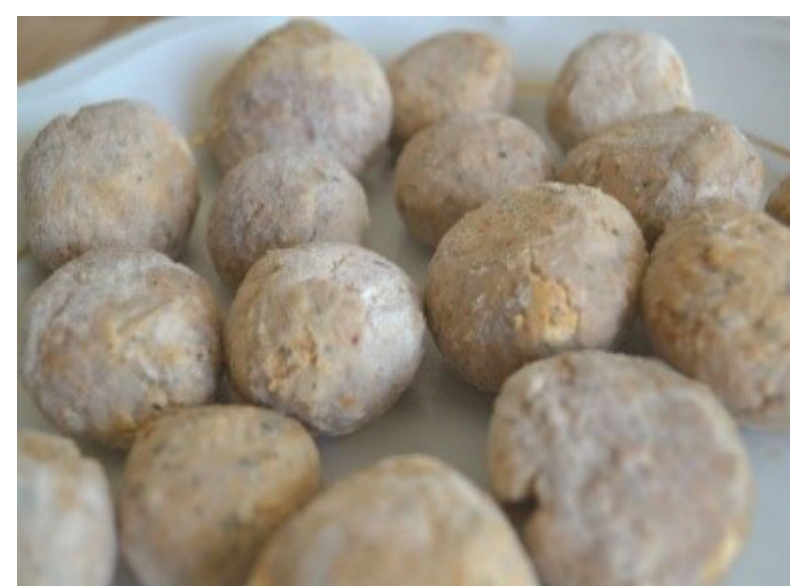

Şekil 12: Antakya Küflü Sürkü

\section{Malkara Eski Kaşar Peyniri}

Evliya Çelebi'nin Seyahatname'sine konu olmuş Malkara'nın kaşkavalı (kaşar peyniri), Selanik'ten İstanbul'a giden yol üzerinde bulunan Malkara ilçesinde üretilen yöresel bir peynirdir. Özellikle yöreye özgü olan Lathyrus L. (mürdümük), Bart (yabani yonca), Medicagopolymorpha L. (tüylü yonca), Medicagofalcata L. (sarıçiçekli yonca), Avenaelatius L. (yüksek çayır yulafi), Thymuslongicaulis C. Presl (uzun gövdeli kekik) ile beslenen koyun, keçi ve ineklerin sütünden üretilmektedir. Koyu saman sarıs1 renkte, sert yapıl1, silindirik formda tam olgunlaşmış peynir, pişmiş, kremamsı, meyvemsi ve fındığımsı bir tada sahiptir (Karaca, 2016; TPE, 2019).

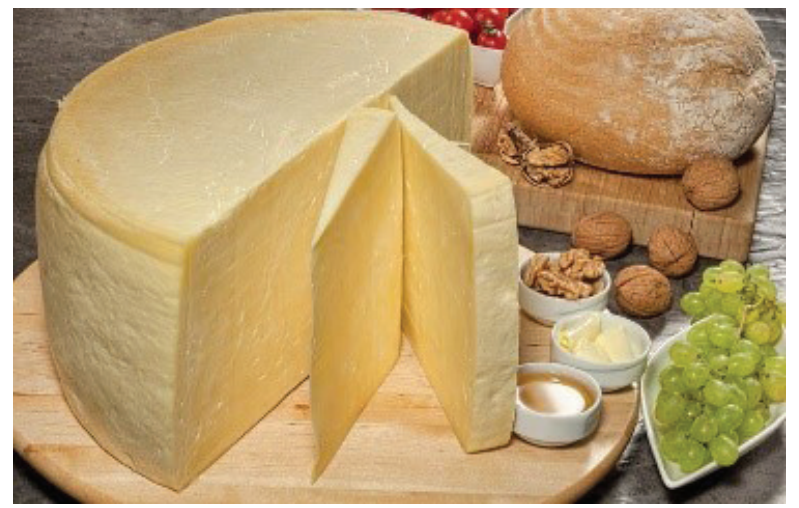

Şekil 13: Malkara eski kaşar peyniri

\section{Van Otlu Peyniri}

Van otlu peynirini diğer peynirlerden ayıran en önemli özellikler, içine katılan otlar ve doğal meralarda otlatılan koyunlardan sağılan taze sütten elde edilmesidir. Üretiminde kullanılan otların en önemli özelliği koliform grubu bakterilere karşı antimikrobiyal etkiye sahip olmasıdır. Ayrıca peynirin kendine özgü renk, tat, koku ve görüntüsünün söz konusu otlardan kaynaklandığı bildirilmektedir (Yenipınar ve ark., 2014). Van otlu peyniri kekik tadında, hafif sarımsak ve kekik kokusundadır. Orta sertlikte peynirler grubunda yer alan peynir küçük gözenekli yapısının yanı sıra dilimlendiğinde saydam bir yapıya sahiptir. Üretiminde tercih edilen sütün bileşimine göre beyazımsı veya sarımtırak renkte olabilmektedir.

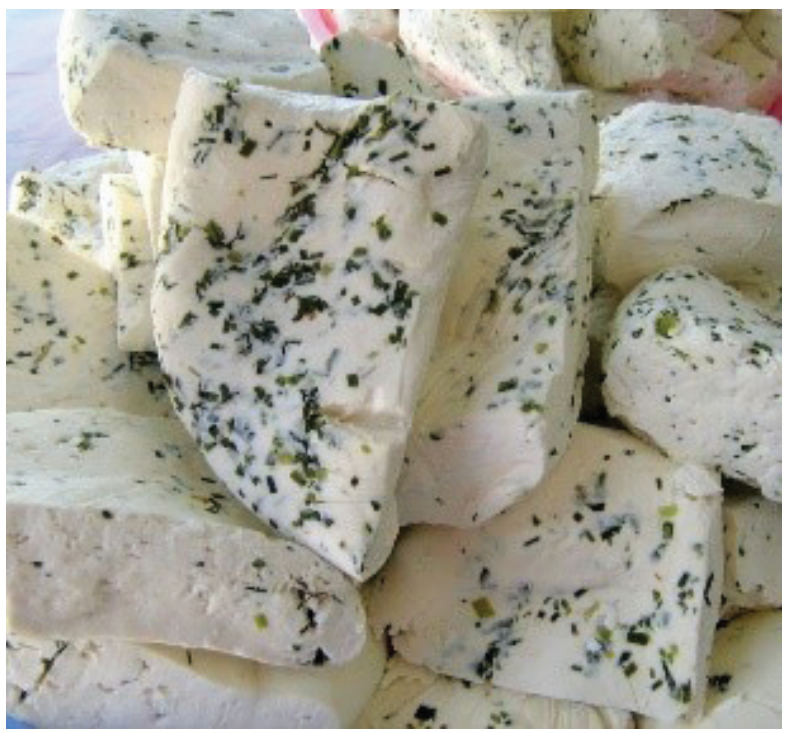

Şekil 14: Van otlu peyniri

Son dönemlerde yerel değerlerin korunması kavramı ön plana çıkmış, turizm hareketlerinde geleneksel ve kültürel değerler önem kazanmıştır. Turist tercihlerinin yerel değerlere sahip çıkan destinasyonlara yönelmesiyle yöresel değerlerin korunması kavramı ön plana çıkmaktadır (Sünnetçioğlu, Can, Durlu- 
Özkaya, 2012). Turistik değer taşıyarak kendi bölgesine katkı sağlayan ürünlerde yöresel değerler arasındaki karmaşanın önlenmesi amaciyla hazırlanan bir yasa ile coğrafi işaretleme yapılmaktadır (Orhan, 2010). Coğrafi işaretli ürünler yemek kültürünü koruyarak turizm faaliyetleri kapsamında bölgenin turizm çekiciliğini artırmakta, ürünün turistler tarafından öncelikle tercih edilmesini sağlamaktadır.

\section{SONUÇ}

Ülkemiz geneline bakıldığında geniş ürün yelpazesi ile süt ve süt ürünleri coğrafi işaretli ürünler arasında dikkat çekmektedir. Çeşitliliği hergeçen günartan peynirlerimizisehem turizm hareketliliğinin artmasında katkı sağlamakta hem de üstün besleyici özelliği ile tüketicilerin doğal, güvenilir, kaliteli ürün arayışına yanıt vermektedir. Geleneksel peynirlerimizin coğrafi işaret ile koruma altına alınması ve tanınmamış lezzetlerin gün yüzüne çıkması için özellikle yerel üretim yapan işletmelerin korunması gastronomi turizmi açısından oldukça önemlidir. $\mathrm{Bu}$ amaçla ülkemizin zengin geleneksel ürünlerinin endüstriyel boyuta taşınması hususunda da oldukça hassas davranmak gerektiği açıktır. Kendine özgü karakteristiklerini kaybetmeden, ülke geneline tanıtılmış ve endüstriyel boyutta üretilebilen coğrafi işaretli lezzetler hem tüketicinin daha kolay ulaşmasına imkân tanıyacak hem de üreticiyi memnun edecektir. Türkiye genelinde coğrafi işaretli ürünlerin sayısı gün geçtikçe artmasına rağmen bölgelere ait geleneksel peynir skalamızın çok daha geniş olduğu ve mevcut potansiyelin unutulmaya yüz tutmadan değerlendirilmesi gerektiği aşikârdır.

\section{KAYNAKÇA}

Akyüz, N., Gülümser, S. (1984). Yozgat çanak peynirinin yapılışı, bileşimi ve olgunlaştırılması. Gıda, 9(4), 232-238.

Ayber, İ. (2005). Sınai Mülkiyet Hakları ile ilgili uluslararası kuruluşlar (WIPO DTÖ, AB, TPE.). Uzmanlık Tezi, Türk Patent Enstitüsü Markalar Dairesi Başkanlığı, Ankara.

Baran, D., Topçu, Y. (2018). Coğrafi işaretli Erzurum küflü peynirinin tüketici tercihlerine dayalı pazarlama taktik ve stratejileri. Kahramanmaraş Sütçü İmam Üniversitesi Tarım ve Doğa Dergisi, 21(2), 191-202.

Durlu-Özkaya, F., Gün, İ. (2007). Anadolu'da peynir kültürü. ICANAS, Uluslararası Asya ve Kuzey Afrika Çalışmaları Kongresi, 10-15 Eylül, Ankara, Türkiye. Özet kitabı, s.485.

Ekinci, M. B. (2014). Coğrafi işaretlemede kullanılan moleküler biyolojik teknikler. 4. Geleneksel Gidalar Sempozyumu, 17-19 Nisan 2014, Adana, Türkiye. Bildiriler kitabı, s.395.

Gökovalı, U. (2007). Coğrafi işaretler ve ekonomik etkileri: Türkiye örneği. İktisadi ve İdari Bilimler Dergisi, 21(2), 141-160.

Gürsu-Doğu, R. P. (2008). Avrupa Birliği’nde kalite politikası ve Türkiye'nin uyumu. AB Uzmanlık Tezi, Tarım ve Köy İşleri Bakanlığı Dış İlişkiler ve AB Koordinasyon Dairesi Başkanlığı, Ankara.

Hayaloğlu, A. A., Özer, B. (2011). Peynir Biliminin Temelleri. Sidas Medya, İzmir, Türkiye.

İşleyici, Ö., Sancak, Y. C. Morul. (2011). Divle tulum peynirinde Aflatoksin M1 düzeyi üzerine bir araştırma. Yüzüncü Y1l Üniversitesi Veteriner Fakültesi Dergisi. 22(2), 105-110. 
Karaca, O. B. (2016). Geleneksel peynirlerimizin gastronomi turizmindeki önemi. Journal of Tourism and Gastronomy Studies, 4(2), 17-39.

Orhan, A. (2010). Yerel değerlerin turizm ürününe dönüştürülmesinde "Coğrafi İşaretlerin” kullanımı: İzmit pişmaniyesi örneği. Anatolia Turizm Araştırmaları Dergisi. 21(2), 243-254.

Sünnetçioğlu, S., Can, A., Durlu-Özkaya, F. (2012). Yavaş turizmde coğrafi işaretlemenin önemi. 13. Ulusal Turizm Kongresi, 6-9 Aralık, Antalya. Bildiriler kitabı, s. 953-962.

Şahin, A. Meral, Y. (2012). Türkiye'de coğrafi işaretleme ve yöresel ürünler. Türk Bilimsel Derlemeler Dergisi, 5(2), 88-92.

Şentürk, B. (2011). Coğrafi işaretlerin ekonomik etkileri: mikro ve makro açıdan bir değerlendirme, Muğla Üniversitesi, Yayınlanmamış Yüksek Lisans Tezi.

Tekelioğlu, Y., Demirer, R. (2008). Küreselleşme Sürecinde Yöresel Ürünler ve Coğrafi İşaretlerin Geleceği. Küreselleşme. Demokratikleşme ve Türkiye Uluslararası Sempozyumu, 27-30 Mart, Antalya. Bildiriler kitab1, s.715-730.
Topçu, Y. (2018). Erzurum İli Süt Sı̆̆ırcılığı İşletmelerinin Sermaye Yapısına Dayalı Risk Düzeyleri. Yeni Yüzyıl Üniversitesi Tarım Bilimleri Dergisi, 28(2), 154-160.

Türkiye Esnaf ve Sanatkârları Konfederasyonu (2019). Sinai Mülkiyet Hakları Bilgi Sitesi. http://www.tesk.org.tr/tr/ calisma/sinai/cografi.html

Türkiye Patent Enstitüsü (2019). Coğrafi İşaretler ve Geleneksel Ürün Adları Başvuru Kilavuzu. https://www.turkpatent.gov.tr/TURKPATENT /resources/temp/6B3F914C-E72C-437C8A30-F50C51DE0A23.pdf

Türkiye'nin Coğrafi İşaretleri (2018a). Antakya sürkü (Antakya Çökeleği) (No:330Mahreç İşareti). https://www.ci.gov.tr/Files/ GeographicalSigns/330.pdf

Türkiye'nin Coğrafi İşaretleri (2018b). Antakya küflü sürkü (Antakya Çökeleği) (No:359- Mahreç İşareti). https://www.ci.gov. tr/Files/GeographicalSigns/359.pdf

Yenipınar, U., Köşker, H. ve Karacaoğlu, S. (2014). Turizmde yerel yiyeceklerin önemi ve coğrafi işaretleme: Van otlu peyniri. Journal of Tourism and Gastronomy Studies, 2(2), 13-23. 